\title{
Instant climate model gears up
}

A climate simulator that started life in a doctoral dissertation is being adopted by negotiators to assess their national greenhouse-gas commitments ahead of December's climate summit in Copenhagen.

Dubbed C-ROADS - for Climate

Rapid Overview and Decision-support Simulator - the tool translates complex climate modelling into readily digestible predictions. Using data on greenhousegas emissions input by country or region over a given period, the simulator projects temperatures, sea level and atmospheric carbon dioxide concentrations to 2100 .

The tool hit the headlines last week when Robert Corell, chairman of the Washingtonbased Climate Action Initiative, made a dire assessment: even with all the international pledges to reduce greenhouse-gas emissions, including a yet-to-be-enacted commitment by the United States, by the end of this century global average temperature will still outpace the $2{ }^{\circ} \mathrm{C}$ increase targeted by the $\mathrm{G} 8$ countries and others. "We're headed to a 4-degree world," Corell told reporters at a press conference in Washington DC. "We don't want to go there."

C-ROADS has its origins in 1997 doctoral work by Thomas Fiddaman, now a modeller with Ventana Systems in Harvard, Massachusetts. The current version represents a collaboration between Ventana, researchers at the Massachusetts Institute of Technology (MIT) in Cambridge and the Sustainability Institute in Hartland, Vermont.

The tool made its debut in the policy world last year during a global-warming war game in Washington DC (see http://tinyurl. com/climgame), and has since been picked up by climate negotiators in the United States and Europe. Earlier this month, modellers on the C-ROADS team travelled to Beijing to train Chinese negotiators on the software.

The goal is to distribute C-ROADS to all parties so that everybody is working off of the same baseline in evaluating proposals, says Andrew Jones, who heads up the initiative at the Sustainability Institute. "We want to get a lot of the bickering over the different numbers out of the way," he says.

The team has calibrated C-ROADS against global climate models used by the Intergovernmental Panel on Climate
Change (IPCC). Unlike those, it can be run on a laptop and produces instant results. Users can adjust dates and emissions from all of the major emitters and groups of developing countries, providing immediate feedback on the likely effects of any given policy commitments.

An independent team led by climatologist Robert Watson of the University of East Anglia in Norwich, UK, reviewed the model and recommended in March that the United Nations consider adopting it as a formal tool to support the climate negotiations. That hasn't happened yet, but modellers with the C-ROADS team are attending UN climate meetings to help negotiators assess policy proposals.

C-ROADS tracks historical data well and generally performs in line with average IPCC modelling results, says John Sterman, an MIT management professor who works on the project.

Sterman says a key problem with global-warming policy is the time lag between today's emissions and the problems they cause, which can be decades down the road. The model attempts to get around that by allowing policy-makers - and the public, through a simplified version on the Climate Interactive website (http://climateinteractive.org) - to see the likely consequences of their decisions immediately. "It's not that the other models are flawed," Sterman says. "They are opaque to the policy-makers."

Jones says that the model produces warming of $4.5^{\circ} \mathrm{C}$ by 2100 for business as usual and $3.8^{\circ} \mathrm{C}$ based on the targets announced in March. Taking into account all the latest pledges by countries, including a commitment from Russia this summer, the model's current reading is $3.5^{\circ} \mathrm{C}$.

"The doom and gloom story is getting $90 \%$ of the attention," he says, "but now we're at $3.5^{\circ} \mathrm{C}$. The global climate deal is getting better over time."

Still, global leaders made little headway on climate last week, at both a UN summit in New York and a meeting of the G20 in Pittsburgh, Pennsylvania. Leaders of the G20 did, however, agree to phase out fossilfuel subsidies while providing "targeted support for the poorest".

Jeff Tollefson

For more, see nature.com/roadtocopenhagen. 